American Journal of Animal and Veterinary Sciences 3 (1): 23-27, 2008

ISSN 1557-4555

(C) 2008 Science Publications

\title{
Cellular and Some Biochemical Changes in Blood and Peritoneal Fluid Constituents in Awassi Lambs Following Elective Castration
}

\author{
${ }^{1}$ Mohammad B.F. AL-Zghoul, ${ }^{2}$ Raida K. AL-Rukibat, ${ }^{3}$ Abdelsalam Q. Talafha, \\ ${ }^{3}$ Omar Ababneh and ${ }^{3}$ Zuhair A. Bani Ismail \\ ${ }^{1}$ Department of Basic Medical Veterinary Sciences, \\ ${ }^{2}$ Department of Pathology and Animal Heath, \\ ${ }^{3}$ Department Clinical Veterinary Sciences, Faculty of Veterinary Medicine, \\ Jordan University of Science and Technology, P.O. Box 3030, Irbid 22110, Jordan
}

\begin{abstract}
No reports could be cited in the recent literature concerning the effects of surgical castration on blood and peritoneal fluid constituents in lambs. The purpose of this study was to evaluate the effects of surgical castration on cellular and some biochemical parameters of blood and peritoneal fluid in Awassi lambs. Eight, clinically healthy, 5-month-old, Awassi lambs were surgically castrated. Peritoneal fluid and blood samples were collected prior to castration (day 0) and on days 1, 3 and 7 post castration. Total nucleated cell count (TNCC) was determined using an electric cell counter. Total protein (TP), albumin, fibrinogen, creatinine, urea, glucose, alkaline phosphatase (ALP), aspartate aminotransferase (AST) and lactate dehydrogenase (LDH) concentrations were analyzed using commercially available kits. Following castration, the number of peripheral fluid white blood cells (WBC) and the percentage of neutrophils significantly increased $(\mathrm{p}<0.05)$ while the percentage of lymphocytes significantly decreased $(\mathrm{p}<0.05)$. The blood fibrinogen, urea, creatinine, glucose, ALP, AST and LDH concentrations significantly increased $(\mathrm{p}<0.05)$. However, TP concentrations did not change. In the peritoneal fluid analysis, the total WBC count and the percentage of neutrophils significantly increased $(\mathrm{p}<0.05)$ while the percentage of monocytes significantly decreased $(\mathrm{p}<0.05)$ following the operation. There was no significant change $(p>0.05)$ in the percentage of lymphocytes in the peritoneal fluid. The concentration of peritoneal fluid TP, urea, creatinine, glucose, ALP and AST significantly increased $(\mathrm{p}<0.05)$ while LDH concentration did not change. Results of this study show that changes in the blood and peritoneal fluid cellular and biochemical components are likely to follow elective surgical castration in lambs. These changes must be taken in consideration when peritoneal fluid samples from lambs are evaluated for the diagnosis of abdominal diseases.
\end{abstract}

Key words: Awassi lambs, castration, inflammation, peritoneal fluid

\section{INTRODUCTION}

The parietal tonics that encase the testicles are a continuation of the parietal peritoneum. Trauma to these tunics, such as due to surgical castration could result in contamination of the peritoneal cavity and therefore post-operative inflammation. In ruminants, changes in peritoneal fluid constituents have been reported after left-sided displacement of the abomasum, traumatic reticuloperitonitis, septic peritonitis and exploratory celiotomy and omentopexy $\mathrm{y}^{[1,2,3]}$.

Inflammation of the peritoneal membrane results in the effusion of large amounts of fluid containing various inflammatory cells and mediators into the peritoneal cavity ${ }^{[4]}$. Clinical diagnosis of peritonitis depends on the demonstration of changes in the peritoneal fluid cellular and biochemical constituents $^{[2,3,4,5]}$. In normal, non-pregnant, Awassi sheep, peritoneal fluid TNCC values of $3.6 \times 10^{3}$ cells $\mu \mathrm{L}^{-1}$ and $16 \%$ neutrophils were considered normal ${ }^{[6]}$.

The effects of castration on animal welfare and stress responses have been well-studied and recognized in lambs ${ }^{[7,8]}$. However, no reports could be cited in the recent literature concerning the effects of castration on peritoneal fluid as a possible cause for peritonitis. Clinically, it is important to establish whether this routine surgical procedure has a significant effect on various cellular and biochemical parameters in the blood and peritoneal fluid in lambs. Because of the

Corresponding Author: Mohammed B.F. AL-Zghoul, Department of Basic Medical Veterinary Sciences, Faculty of Veterinary Medicine, Jordan University of Science and Technology P.O. Box 3030, Irbid 22110, Jordan 
possible changes in peritoneal fluid constituents, interpretation of peritoneal fluid analysis becomes very difficult after surgery. Therefore, the aims of this study were to determine if castration induces changes in blood and peritoneal fluid cellular and biochemical constituents and to provide data that could help in interpreting results of peritoneal fluid analysis in recently castrated lambs.

\section{MATERIALS AND METHODS}

Eight, 5-month-old, clinically healthy, male Awassi lambs were used in this study. Research protocols and procedures were approved and supervised by the Animal Care and Use Committee at Jordan University of Science and Technology (JUST-ACUC). Lambs were kept in a closed university farm and fed a regular fattening ration containing $16-18 \%$ crude protein. Four weeks prior to the operation, they were de-wormed using fenbendazole $\left(10 \mathrm{mg} \mathrm{kg}^{-1}\right)$ and antitetanus prophylactic treatment was administered. Surgical castration was performed by excising the distal one-third of the scrotum as described previously ${ }^{[9]}$.

Five to seven milliliters of whole blood was collected aseptically from the jugular vein using disposable needles and vacutainer tubes with and without EDTA at days 0, 1, 3 and 7 post-castration. Hematological analysis was performed immediately using an electric cell counter (ABC Vet hematology analyzer, ABX Diagnostics, Maizy, France). Serum was obtained by allowing the blood to clot at room temperature, centrifuged at $5000 \mathrm{~g}$ for $10 \mathrm{~min}$ at $4{ }^{\circ} \mathrm{C}$ and stored at $-20{ }^{\circ} \mathrm{C}$ until analyzed.

Abdominocentesis was performed on days 0, 1, 3 and 7 post-castration. Peritoneal fluid samples were collected from standing lambs from the lower right flank region as described previously ${ }^{[6]}$. Briefly, wool over the site was clipped, then the skin was scrubbed with Povidone-Iodine solution and washed with alcohol. A 20-gauge, 1.5-inch needle was used to aspirate the peritoneal fluid, which was collected by gravity flow into 4-ml EDTA-coated tubes (BD Vacutainer, Belliver Industrial Estate, Plymouth, UK). Approximately 1-2 mL of fluid was collected from each animal. In case no peritoneal fluid was obtained from the first attempt, a second attempt was performed in an adjacent place. In addition, peritoneal fluid samples were obtained from non castrated herdmates to evaluate the effect of repeated abdominocentesis on various parameters.

Peritoneal fluid samples were evaluated for color and transparency. Total nucleated cell count of peritoneal fluid was determined using electric cell counter (ABC Vet hematology analyzer, ABX Diagnostics, Maizy, France). Straight slide smears from the fluid were prepared. Peritoneal fluid samples were centrifuged at $1500 \mathrm{~g}$ for 10 minutes. The fluid supernatant was stored at $-20{ }^{\circ} \mathrm{C}$ until analyzed. Slide smears were also prepared from the sediment after resuspension in several drops of supernatant. All fluid and blood films were stained with Wright's stain and examined for cellular morphology. A 100-cell differential cell count was performed.

Serum and the supernatant of the fluid was analyzed for TP (Biuret method), albumin (BCG method), urea (Colorimetric method), creatinine (Kinetic method), glucose (GOD-PAP method), LDH (IFCC method), AST (IFCC method) and ALP (Kinetic method) using commercially available kits and reagents according to manufacturers recommendations.

Values were expressed in means \pm standard deviation from the mean (SD). The effects of castration and days after castration were analyzed using repeated measures analysis of variance, Friedman's test. When significant difference was identified, Dunns's post test was used. Statistical analyses were performed using Graphpad Prism for windows (Graphpad, San Diego, CA). The difference was considered significant at values of $\mathrm{p}<0.05$.

\section{RESULTS}

All lambs involved in the study maintained normal appetite and attitude throughout the study period. Slight dehydration $(<7 \%)$ was observed clinically by assessing skin elasticity in the first $12-24 \mathrm{~h}$ post-operatively. None of the castrated lambs developed surgical site infection following castration. Entrocentesis was not encountered in any attempt during peritoneal fluid collection.

Mean peripheral WBC count was significantly elevated on day 1 and continued to be elevated throughout the study period. Neutrophil counts were increased significantly $(\mathrm{p}<0.05)$ on day 3 postcastration while lymphocyte counts were significantly decreased. Both values returned to normal on day 7 . The percentages of monocytes, eosinophils and basophils in the blood did not change significantly during the sampling period (Table 1).

In the serum biochemical profile (Table 2), there was no significant change ( $\mathrm{p}>0.05)$ in TP concentration throughout the study. Albumin concentration was significantly elevated $(\mathrm{p}<0.05)$ on day 1 and returned to normal on days 3 and 7. Plasma fibrinogen and glucose concentrations were significantly elevated $(\mathrm{p}<0.05)$ on days 1 and 3 and returned to normal on day 7. Blood 
American J. Animal \& Vet. Sci., 3 (1): 23-27, 2008

Table 1: Means $\pm \mathrm{SD}$ and ranges of peripheral total white blood cell counts and percentages of differential leukocytes in 8 Awassi lambs underwent elective castration*

\begin{tabular}{lllll}
\hline Day & 0 & 1 & 3 & 7 \\
\hline WBC $^{1}\left(10^{3}\right.$ cells $\left.\mu \mathrm{L}^{-1}\right)$ & $6.9 \pm 1.6^{\mathrm{a}}(4-9)$ & $14.8 \pm 4.4^{\mathrm{b}}(9-21)$ & $16.5 \pm 4.5^{\mathrm{b}}(11-23)$ & $12.6 \pm 2^{\mathrm{b}}(9-16)$ \\
Neutrophils & $23.5 \pm 2.7^{\mathrm{a}}(20-27)$ & $27.9 \pm 4.5^{\mathrm{a}}(23-35)$ & $48 \pm 10.9^{\mathrm{b}}(35-67)$ & $26 \pm 1.6^{\mathrm{a}}(24-27)$ \\
Lymphocytes & $68.5 \pm 2.2^{\mathrm{a}}(65-72)$ & $69 \pm 6^{\mathrm{a}}(59-79)$ & $45.5 \pm 17.3^{\mathrm{b}}(20-70)$ & $65.7 \pm 6.7^{\mathrm{a}}(57-78)$ \\
Monocytes & $4 \pm 1.3^{\mathrm{a}}(2-6)$ & $4 \pm 1.3^{\mathrm{a}}(2-6)$ & $3.5 \pm 1.8^{\mathrm{a}}(1-6)$ & $4 \pm 1.3^{\mathrm{a}}(3-7)$ \\
Eosinophils & $3.5 \pm 1.6^{\mathrm{a}}(1-6)$ & $3.5 \pm 2.2^{\mathrm{a}}(1-7)$ & $2.25 \pm 1.5^{\mathrm{a}}(0-5)$ & $3.25 \pm 1.6^{\mathrm{a}}(1-6)$ \\
Basophils & $0.5 \pm 0.4^{\mathrm{a}}(0-1)$ & $1 \pm 1.1^{\mathrm{a}}(0-3)$ & $0.9 \pm .5^{\mathrm{a}}(0-2)$ & $0.8 \pm 0.6^{\mathrm{a}}(0-2)$ \\
\hline
\end{tabular}

* Means in rows with different superscript letter are statistically different at $\mathrm{p}<0.05$.

${ }^{1}$ WBC: White blood cells

Table 2: Means $\pm \mathrm{SD}$ and ranges of some serum biochemical values in 8 Awassi lambs underwent elective castration*

\begin{tabular}{lllll}
\hline Day & 0 & 1 & 3 & 7 \\
\hline Total Protein $\left(\mathrm{g} \mathrm{dL}^{-1}\right)$ & $5.8 \pm 0.4^{\mathrm{a}}(5.5-6.5)$ & $7.5 \pm 1.4^{\mathrm{a}}(5.5-9.5)$ & $5.8 \pm 1.3^{\mathrm{a}}(5-9)$ & $5.5 \pm 0.7^{\mathrm{a}}(5-7)$ \\
Albumin $\left(\mathrm{g} \mathrm{dL}^{-1}\right)$ & $2.9 \pm 0.4^{\mathrm{a}}(2.3-3.5)$ & $4.2 \pm 0.45^{\mathrm{b}}(3.6-4.7)$ & $3.9 \pm 0.56^{\mathrm{a}}(3.5-4.5)$ & $3.8 \pm 0.24^{\mathrm{a}}(3.4-4)$ \\
Fibrinogen $\left(\mathrm{mg} \mathrm{dL}^{-1}\right)$ & $285 \pm 108^{\mathrm{a}}(142-428)$ & $574 \pm 124^{\mathrm{b}}(428-714)$ & $625 \pm 106^{\mathrm{c}}(428-718)$ & $460 \pm 110^{\mathrm{a}}(250-571)$ \\
Creatinine $\left(\mathrm{mg} \mathrm{dL}^{-1}\right)$ & $0.8 \pm 0.4^{\mathrm{a}}(0.3-1.4)$ & $1.5 \pm 0.1^{\mathrm{b}}(1.4-1.7)$ & $1.4 \pm 0.05^{\mathrm{b}}(1.4-1.5)$ & $1.4 \pm 0.15^{\mathrm{b}}(1.2-1.6)$ \\
Urea $\left(\mathrm{mg} \mathrm{dL}^{-1}\right)$ & $19.5 \pm 4.5^{\mathrm{a}}(12-28)$ & $26.5 \pm 5^{\mathrm{a}}(20-35)$ & $31.8 \pm 3.7^{\mathrm{b}}(25-35)$ & $26.5 \pm 3.5^{\mathrm{a}}(20-30)$ \\
Glucose $\left(\mathrm{mg} \mathrm{dL}^{-1}\right)$ & $72.5 \pm 10.5^{\mathrm{a}}(60-92)$ & $101.6 \pm 17^{\mathrm{b}}(86-123)$ & $91.8 \pm 11.5^{\mathrm{b}}(80-110)$ & $90 \pm 5.3^{\mathrm{a}}(90-100)$ \\
ALP $\left(\mathrm{U} \mathrm{L} \mathrm{L}^{-1}\right)^{1}$ & $267 \pm 62^{\mathrm{a}}(200-400)$ & $253 \pm 30^{\mathrm{a}}(200-280)$ & $237 \pm 14^{\mathrm{b}}(220-250)$ & $196 \pm 12^{\mathrm{a}}(180-220)$ \\
AST $\left(\mathrm{UL} \mathrm{L}^{-1}\right)^{2}$ & $70 \pm 5^{\mathrm{a}}(60-78)$ & $112 \pm 13^{\mathrm{b}}(90-130)$ & $124 \pm 10^{\mathrm{b}}(100-130)$ & $92 \pm 4.5^{\mathrm{a}}(85-100)$ \\
LDH $\left(\mathrm{U} \mathrm{L}^{-1}\right)^{3}$ & $340 \pm 37^{\mathrm{a}}(320-350)$ & $500 \pm 90^{\mathrm{b}}(430-650)$ & $410 \pm 57^{\mathrm{a}}(350-500)$ & $390 \pm 48^{\mathrm{a}}(310-430)$ \\
\hline
\end{tabular}

* Means in rows with different superscript letter are statistically different at $\mathrm{p}<0.05$.

${ }^{1}$ ALP: Alkaline phosphatase, ${ }^{2}$ AST: Aspartate aminotransferase, ${ }^{3} \mathrm{LDH}$ : Lactate dehydrogenase

Table 3: Means \pm SD and ranges of RBC, TNCC and percentage neutrophils, lymphocytes and monocytes in peritoneal fluid from 8 Awassi lambs underwent elective castration*

\begin{tabular}{lllll}
\hline Day & 0 & 1 & 3 & 7 \\
\hline RBC $^{1}\left(10^{4}\right.$ cells $\left.\mu \mathrm{L}^{-1}\right)$ & $1.5 \pm 0.5^{\mathrm{a}}(1-2)$ & $11.8 \pm 8^{\mathrm{b}}(1-25)$ & $12.8 \pm 10.5^{\mathrm{b}}(3-27)$ & $4.6 \pm 2.6^{\mathrm{a}}(2-10)$ \\
TNCC $^{2}\left(10^{3}\right.$ cells $\left.\mu \mathrm{L}^{-1}\right)$ & $1.25 \pm 0.8^{\mathrm{a}}(0.6-2.7)$ & $17.8 \pm 20.45^{\mathrm{a}}(0.7-45.5)$ & $14.3 \pm 7.1^{\mathrm{b}}(4.7-24.2)$ & $1.5 \pm 1.0^{\mathrm{a}}(0.7-3.4)$ \\
Neutrophils & $7 \pm 6^{\mathrm{a}}(2-20)$ & $65.8 \pm 24.4^{\mathrm{b}}(11-84)$ & $55 \pm 9.6^{\mathrm{b}}(41-64)$ & $8 \pm 2.8^{\mathrm{a}}(4-12)$ \\
Lymphocytes & $26 \pm 19.25^{\mathrm{a}}(9-70)$ & $22 \pm 4.5^{\mathrm{a}}(14-26)$ & $34 \pm 14^{\mathrm{a}}(6-52)$ & $33.5 \pm 8.8^{\mathrm{a}}(17-45)$ \\
Monocytes & $64.3 \pm 21.5^{\mathrm{a}}(20-85)$ & $21.4 \pm 17^{\mathrm{b}}(8-57)$ & $16.8 \pm 9.4^{\mathrm{b}}(5-34)$ & $68.25 \pm 6^{\mathrm{a}}(56-78)$ \\
\hline
\end{tabular}

* Means in rows with different superscript letter are statistically different at $\mathrm{p}<0.05$.

${ }^{1} \mathrm{RBC}$ : Red blood cells, ${ }^{2} \mathrm{TNCC}$ : Total nucleated cell count

creatinine concentration was significantly elevated $(\mathrm{p}<0.05)$ on day 1 and remained high throughout the study period. There was a significant increase $(\mathrm{p}<0.05)$ in urea concentration on day 3 with values returned to normal on day 7. Serum activity of ALP was significantly elevated $(\mathrm{p}<0.05)$ on day 3 and returned to normal on day 7. Serum activities of LDH and AST were increased significantly $(\mathrm{p}<0.05)$ on day 1 and returned to normal on days 3 and 7, respectively.

Following castration, the peritoneal fluid was slightly blood tinged in all animals. There was a significant increase $(\mathrm{p}<0.05)$ in mean peritoneal fluid red blood cell (RBC) count on days 1 and 3 with values returned to normal on day seven (Table 3). The mean peritoneal fluid TNCC was significantly elevated $(\mathrm{p}<0.05)$ on day 3 and returned to normal in all animals on day 7. The mean percentage of neutrophils in the peritoneal fluid significantly increased $(\mathrm{p}<0.05)$ on days 1 and 3 and returned to normal on day 7 . The mean percentage of monocytes in the peritoneal fluid declined significantly $(\mathrm{p}<0.05)$ on days 1 and 3 and returned to normal on day 7 . There was no significant change $(p>0.05)$ in the percentage of lymphocytes in the peritoneal fluid throughout the study period.

Microscopic examination of slide smears prepared from the peritoneal fluid did not reveal any extra or intra cellular bacteria.

In the peritoneal fluid biochemical analysis (Table 4), the TP and albumin concentrations were significantly elevated $(\mathrm{p}<0.05)$ on day 3 and returned to normal on day 7 . The creatinine concentration was significantly elevated on day 1 and remained high through out the study period, while urea concentration was significantly elevated $(\mathrm{p}<0.05)$ on days 3 and 7 . Peritoneal fluid glucose concentration and ALP activities were significantly elevated $(p<0.05)$ on days 1 and 3 and returned to normal on day 7. Peritoneal fluid AST activities were significantly elevated $(\mathrm{p}<0.05)$ on day 3 and returned to normal on day 7. There was no significant change $(\mathrm{p}>0.05)$ in LDH activities throughout the study period. 
American J. Animal \& Vet. Sci., 3 (1): 23-27, 2008

Table 4: Means \pm SD and ranges of some biochemical values of peritoneal fluid from 8 Awassi lambs underwent elective castration*

\begin{tabular}{lllll}
\hline Day & 0 & 1 & 3 & 7 \\
\hline Total Protein $\left(\mathrm{g} \mathrm{dL}^{-1}\right)$ & $1.7 \pm 1^{\mathrm{a}}(0.8-3.8)$ & $2.4 \pm 0.35^{\mathrm{a}}(2.2-3.2)$ & $4 \pm 0.5^{\mathrm{b}}(3.6-4.9)$ & $1.9 \pm 0.5^{\mathrm{a}}(1.3-2.1)$ \\
Albumin $\left(\mathrm{g} \mathrm{dL}^{-1}\right)$ & $1.3 \pm 0.7^{\mathrm{a}}(0.5-2.6)$ & $1.6 \pm 0.6^{\mathrm{a}}(1.1-2.6)$ & $3.2 \pm 0.6^{\mathrm{b}}(2.2-3.7)$ & $1.6 \pm 0.4^{\mathrm{a}}(1.3-2.3)$ \\
Creatinine $\left(\mathrm{mg} \mathrm{dL}^{-1}\right)$ & $0.95 \pm 0.4^{\mathrm{a}}(0.3-1.5)$ & $1.3 \pm 0.1^{\mathrm{b}}(1.2-15)$ & $1.3 \pm 0.1^{\mathrm{b}}(1.2-1.5)$ & $1.4 \pm 0.12^{\mathrm{b}}(1.3-1.7)$ \\
Urea $\left(\mathrm{mg} \mathrm{dL}^{-1}\right)$ & $13.3 \pm 2.5^{\mathrm{a}}(11-18)$ & $23.7 \pm 6.7^{\mathrm{a}}(15-38)$ & $30.7 \pm 2.4^{\mathrm{b}}(27-34)$ & $27.7 \pm 2.7^{\mathrm{b}}(24-33)$ \\
Glucose $\left(\mathrm{mg} \mathrm{dL}^{-1}\right)$ & $67.9 \pm 5.3^{\mathrm{a}}(61-75)$ & $91.2 \pm 12^{\mathrm{b}}(80-109)$ & $95.2 \pm 6.9^{\mathrm{b}}(86-106)$ & $84.4 \pm 5.5^{\mathrm{a}}(76-90)$ \\
ALP $\left(\mathrm{U} \mathrm{L}^{-1}\right)^{1}$ & $15.8 \pm 5.6^{\mathrm{a}}(7-23)$ & $68 \pm 23^{\mathrm{b}}(23-110)$ & $71 \pm 10.6^{\mathrm{b}}(55-89)$ & $24 \pm 7.2^{\mathrm{a}}(14-31)$ \\
AST $\left(\mathrm{U} \mathrm{L}^{-1}\right)^{2}$ & $30 \pm 11^{\mathrm{a}}(14-35)$ & $50 \pm 28^{\mathrm{a}}(23-90)$ & $82 \pm 17^{\mathrm{b}}(45-100)$ & $35 \pm 10^{\mathrm{a}}(22-45)$ \\
LDH $\left(\mathrm{U} \mathrm{L}^{-1}\right)^{3}$ & $99 \pm 27^{\mathrm{a}}(70-130)$ & $82 \pm 7^{\mathrm{a}}(73-95)$ & $81 \pm 9^{\mathrm{a}}(65-90)$ & $74 \pm 7^{\mathrm{a}}(65-85)$ \\
\hline
\end{tabular}

* Means in rows with different superscript letter are statistically different at $\mathrm{p}<0.05$.

${ }^{1}$ ALP: Alkaline phosphatase, ${ }^{2}$ AST: Aspartate aminotransferase, ${ }^{3} \mathrm{LDH}$ : Lactate dehydrogenase

There was no significant effect of repeated abdominocentesis on peritoneal fluid TNCC, RBC counts, differential leukocyte count or any biochemical value (data not shown).

\section{DISCUSSION}

In small ruminants, peritonitis is considered a rare clinical problem. In fact, a thorough search of the current literature yields no reports of peritonitis as a consequence of surgical castration in small ruminants. Eighty seven percent of Awassi lambs involved in this study developed evidence of peritonitis 1-3 days postcastration based on a significant increase in TNCC and neutrophil percentage in the peritoneal fluid above the normal values previously reported by Al-Rukibat et al. $(2006)^{[6]}$.

The total peripheral WBC count and neutrophil percentages increased significantly following the surgery, while lymphocytes decreased. These changes are likely due to reactive leukocytosis and stress ${ }^{[4]}$. This explanation is also supported by the significant increase in serum glucose concentrations on day 1 of the study. In addition, plasma fibrinogen concentrations increased significantly in our study following castration. This increase in fibrinogen levels further indicates the presence of acute peritoneal inflammation. Incisional or spermatic cord infection was not reported in any animal in this study.

The blood urea, ALP, AST, LDH and creatinine concentrations were increased significantly following castration. These changes are likely due to increased catabolic breakdown of tissue and dehydration as a result of post-operative stress.

All peritoneal fluid samples in this study were blood-tinged. This may suggest that some of the white blood cells in the peritoneal fluid samples are due to hemorrhage during or shortly after castration. However, the significant increase in the peritoneal fluid TNCC in the majority of the lambs can not only be due to peripheral blood contamination. It has been reported that in human beings and in horses, free blood in contact with the peritoneum can cause peritonitis $^{[10,11,12,13]}$.

Although bacterial culture of the peritoneal fluid was not performed in this study, neither intra- or extracellular bacteria nor degenerative neutrophils were noted in any peritoneal fluid sample. This indicates that peritonitis developed in these lambs was aseptic and not due to bacterial infection of the abdominal cavity.

Following castration in lambs, the mean concentrations of TP and albumin in the peritoneal fluid increased significantly. This might be due to peritoneal membrane inflammation and subsequent effusion of large molecules to the peritoneal cavity. Similar to these findings, it has been reported that a significant increase in peritoneal fluid protein concentration occurred due to post-operative peritonitis developed due to rumenotomy in goats and after exploratory celiotomy and omentopexy in cattle $\mathrm{e}^{[1,2]}$.

The mean values of peritoneal fluid creatinine, urea, glucose, ALP and AST were significantly elevated following castration. These changes are an indication of peritoneal membrane inflammation. It was found that horses with nonseptic peritonitis had significantly higher peritoneal fluid glucose concentration than horses with septic peritonitis ${ }^{[14]}$. Whether this is true in ruminants is not clear. More case-control studies are warranted in the future to evaluate the effect of septic inflammation on glucose levels in the peritoneal fluid.

In small ruminants, there are no studies to evaluate the effect of repeated abdominocentesis on abdominal fluid TNCC and neutrophil counts. In horses and calves, it has been established that neither enterocentesis nor serial collection of peritoneal fluid has any significant effect on results of peritoneal fluid analysis ${ }^{[10,5]}$. Similarly, in this study, there was no effect of repeated abdominocentesis on peritoneal fluid analyses. 


\section{CONCLUSION}

Nonseptic peritonitis is likely to develop in lambs following elective surgical castration. Although, there were no clinical signs exhibited by lambs in this study, the awareness of this possible post-operative complication is crucial in the planning of the postoperative patient care and in the interpretation of peritoneal fluid constituents concentrations from lambs needed for the diagnosis of other abdominal diseases.

\section{ACKNOWLEDGEMENT}

The authors would like to thank the Deanship of Research at the Jordan University of Science and Technology for sponsoring this project.

\section{REFERENCES}

1. Adamu, S.S., G.O. Egwu and J.T. Malgwi, 1991. Biochemical changes in the peritoneal fluid following rumenotomy in goats. Vet. Res. Comm., 15: 363-367.

2. Anderson, D.E., D. Cornwell, L.S. Anderson, G. St-Jean and A. Desrochers, 1994. Comparison of peritoneal fluid analysis before and after exploratory celiotomy and omentopexy in cattle. Am. J. Vet. Res., 55: 1633-1637.

3. Dehghani, S., S. Nazifi and M.R. Barzegar, 2000. Evaluation of cellular and biochemical parameters of blood and peritoneal fluid following exploratory laporatomy in the goat. J. Vet. Med. Series A., 47: 143-148.

4. Duncan, J.R., K.W. Prasse and E.A. Mahaffey, 1994. Veterinary laboratory medicine. Clinical pathology, 3rd Edn. Iowa State University Press. Iowa, pp: 204-211.

5. Juzwiak, J.S., C.A. Ragle, C.M. Brown, J.D. Krehbiel and R.F. Slocombe, 1991. The effect of repeated abdominocentesis on peritoneal fluid constituents in the horse. Vet. Res. Comm., 15: $177-180$.
6. Al-Rukibat, R.K., Z.A. Bani Ismail, A.M. Al-Majali and M.B. Al-Zghoul, 2006. Peritoneal fluid analysis in adult, non-pregnant Awassi sheep. Vet. Clin. Path., 35: 215-218.

7. Shutt, D.A., L.R. Fell, R. Connell, A.K. Bell, C.A. Wallace and A.I. Smith, 1987. Stress-induced changes in plasma concentrations of immunoreactive beta-endorphin and cortisol in response to routine surgical procedures in lambs. Aust. J. Biol. Sci., 40: 97-103.

8. Shutt, D.A., L.R. Fell, R. Connell and A.K. Bell, 1988. Stress responses in lambs docked and castrated surgically or by the application of rubber rings. Aust. J. Biol. Sci., 65: 5-7.

9. Gilbert, R.O. and S.L. Fubini, 2004. Surgery of the Male Reproductive Tract. In: Farm Animal Surgery, Elsevier, St. Louis, MI. Fubini, S.L. and N.G. Ducharme, (Eds.), pp: 351-359.

10. Schumacher, J., J. Schumacher, J.S. Spano and J. McGuire, 1988. Effects of castration on peritoneal fluid in the horse. J. Vet. Intern. Med., 2: $22-25$.

11. Shearman, D.J.C. and N.D.C. Finlason, 1982. Diseases of gastrointestinal tract and liver. Churchill Livingstone. New York, pp: 365-366.

12. Aach, R.D., 1983. Abdominal pain. In: MacBryde's Signs and Symptoms: Applied pathologic physiology and clinical interpretation. Blacklow, R.S., 6th Edn., pp. 165-179 Lippincott, Philadelphia.

13. Malark, J.A., L.C. Peyton and M.J. Galvin, 1992. Effects of blood contamination on equine peritoneal fluid analysis. J. Am. Vet. Med. Assoc., 201: 1545-1548.

14. Hoogmoed, L.V., L.D. Rodger, S.J. Spier, I.A. Gardner, T.B. Yarbrough and J.R. Snyder, 1999. Evaluation of peritoneal fluid $\mathrm{pH}$, glucose concentration and lactate dehydrogenase activity for detection of septic peritonitis in horses. J. Am. Vet. Med. Assoc., 214: 1032-1036. 